\title{
ANALYSIS OF PERCEPTION OF STUDENTS ON HUMAN RESOURCE ACCOUNTING DISCLOSURES
}

\section{Dr. Jaykumar D. Mistry}

ABSTRACT

Human Resource is a dynamic factor for any organisation. It deserves an equivalent importance along with other physical assets. That is the reason that it must also be integrate in accounting records. In this regards, 175 responses from different students from higher studies like master of commerce and master of business administration etc, have been obtain. Their views and beliefs for disclosures of Human Resource Accounting have been obtain and analysed. This paper attempts to find out the respondents perception of professionals for discourse of human resource accounting details in financial reports.

\section{KEYWORDS : Human Resource Accounting, students' perception, disclosing information}

\section{INTRODUCTION:}

Accounting is fundamentally concerned with the recording of business transitions in a lucid manner so that it will be helpful to management for their decision making. Certain specific rules and regulations follow them. Even it is limited to one particular period. Any expenses incurred in business or any income received, it is immediately recorded in a specific book.

Since, while recording, it is considering whether it is long term or short term, i.e. like revenue nature or capital nature. This rule applied to all transactions, e.g. payment of rent for the building is taken as expense concerned with short term period (revenue) affected to profit and loss of the business. Likewise, the purchase of the building is considered as a capital expense, which is not only connected to the current year but also concerned with the future. Further, depreciator is charged on such asset, i.e. slowly and gradually the value of asset reduced and such reduction (depreciation) will be affected by profit \& loss of such respective financial period.

This ideology can also be applied to the human resource of the organisation. The remuneration paid to human beings in the organization taken as revenue expenses and transferred to Profit \& Loss Account. While human beings of a business organization who contribute to the growth and development of business, are not directly taken as an asset like other assets. Moreover, the value of other assets reduced day by day due to depreciation, but as per one aspect value of human resource will be increased due to increment in their knowledge and experience.

In this way, a primary survey has been conducted with different professionals for disclosure of human resource accounting information. In this regard information have been obtained through questionnaire by total 175 students from higher studies have been and analysed in context with their perception for Human Resource Accounting disclosure.

\section{DESCRIPTIVE ANALYSIS OF STUDENTS RESPONSE:}

The summary of information obtained from employees has been presented in following tables:

Table-1: Students Perception for Disclosure of Human Resource Accounting Information: (PART-I)

\begin{tabular}{|c|c|c|c|c|c|c|}
\hline \multirow{2}{*}{$\begin{array}{l}\text { Sr. } \\
\text { No. }\end{array}$} & \multirow{2}{*}{\multicolumn{2}{|c|}{ Particulars }} & \multicolumn{2}{|c|}{ No. of Responses } & \multirow{2}{*}{$\begin{array}{c}\text { Total } \\
\text { Respondents }\end{array}$} & \multirow[t]{2}{*}{ (\%) } \\
\hline & & & Yes & No & & \\
\hline$(1)$ & \multicolumn{2}{|c|}{ Do you consider Human Resource as an asset? } & 175 & 0 & 175 & 100 \\
\hline (2) & \multicolumn{2}{|r|}{$\begin{array}{l}\text { Do you agree Human Resource of an organisation should be } \\
\text { accounted? }\end{array}$} & 175 & 0 & 175 & 100 \\
\hline \multirow[t]{18}{*}{ (3) } & \multicolumn{6}{|c|}{ If you are agree then which of the following factors you believe to be incorporate for Human Resource Accounting? } \\
\hline & $(\bar{A})$ & No. of Employees & \multicolumn{2}{|c|}{102} & 175 & 58.29 \\
\hline & (B) & Age of Employees & \multicolumn{2}{|c|}{96} & 175 & 54.86 \\
\hline & (C) & $\begin{array}{l}\text { Classification of employees as per their gender and their } \\
\text { working class etc. }\end{array}$ & \multicolumn{2}{|c|}{75} & 175 & 42.86 \\
\hline & (D) & No. of years of experience of the employee within the current firm & \multicolumn{2}{|c|}{109} & 175 & 62.29 \\
\hline & (E) & No. of years of total experience of the employee & \multicolumn{2}{|c|}{100} & 175 & 57.14 \\
\hline & $(\mathrm{F})$ & Amount paid by the firm by way of: & & & & \\
\hline & & (I)Salary & \multicolumn{2}{|c|}{142} & 175 & 81.14 \\
\hline & & (ii)Wages & \multicolumn{2}{|c|}{35} & 175 & 20.00 \\
\hline & & (iii)Bonus & \multicolumn{2}{|c|}{64} & 175 & 36.57 \\
\hline & & (iv)Gratuity & \multicolumn{2}{|c|}{35} & 175 & 20.00 \\
\hline & & (v)Pension & \multicolumn{2}{|c|}{62} & 175 & 35.43 \\
\hline & (G) & Provident Fund Contribution by Employees & \multicolumn{2}{|c|}{93} & 175 & 53.14 \\
\hline & $(\mathrm{H})$ & Provident Fund Contribution by Employer or Firm & \multicolumn{2}{|c|}{85} & 175 & 48.57 \\
\hline & (I) & Employee Welfare Expenses incurred by the Firm & \multicolumn{2}{|c|}{98} & 175 & 56.00 \\
\hline & (J) & Total value of amenities provided by the firm to employees & \multicolumn{2}{|c|}{79} & 175 & 45.14 \\
\hline & $(\mathrm{K})$ & Total amount provided by the firm for employees & \multicolumn{2}{|c|}{105} & 175 & 60.00 \\
\hline & & Average of Responses & \multicolumn{2}{|c|}{95.88} & 175 & 54.79 \\
\hline
\end{tabular}


(PART-II)

\begin{tabular}{|c|c|c|c|c|c|c|c|}
\hline No. & Particulars & SA & $\overline{A G}$ & NU & DA & SDA & Total \\
\hline 1. & $\begin{array}{l}\text { Human Resource is an important asset and should be valued along } \\
\text { with other physical assets of the firm. }\end{array}$ & 113 & 32 & 23 & 1 & 6 & 175 \\
\hline 2. & Human Resource Accounting is not costly. & 37 & 53 & 52 & 25 & 8 & 175 \\
\hline 3. & $\begin{array}{l}\text { Human Resource Accounting should be reported in financial } \\
\text { statements to disclose true and correct picture of the firm. }\end{array}$ & 76 & 45 & 40 & 12 & 2 & 175 \\
\hline 4. & $\begin{array}{l}\text { After considering Human Resource Accounting and disclosure in } \\
\text { Annual Reports, the impression of the organisation increases. }\end{array}$ & 61 & 58 & 43 & 8 & 5 & 175 \\
\hline 5. & $\begin{array}{l}\text { Human Resource Accounting and its disclosure helps to increase } \\
\text { profitability and productivity of the firm. }\end{array}$ & 76 & 50 & 30 & 12 & 7 & 175 \\
\hline 6. & $\begin{array}{l}\text { Human Resource Accounting is helpful for planning, recruitment, } \\
\text { development and control of Human Resource in organisation. }\end{array}$ & 75 & 54 & 29 & 11 & 6 & 175 \\
\hline 7. & Human Resource Accounting is useful for decision-making. & 69 & 57 & 26 & 18 & 5 & 175 \\
\hline 8. & $\begin{array}{l}\text { Human Resource Accounting and its disclosure should be made } \\
\text { mandatory for organisation. }\end{array}$ & 44 & 60 & 49 & 15 & 7 & 175 \\
\hline 9. & $\begin{array}{l}\text { Human Resource Accounting and its disclosure helps investors to } \\
\text { take decision for investment in the company. }\end{array}$ & 47 & 67 & 42 & 11 & 8 & 175 \\
\hline 10. & $\begin{array}{l}\text { Human Resource Accounting makes positive impact in the eyes of } \\
\text { stakeholders like shareholders, debenture holders, banks, } \\
\text { government, creditors, public and employees etc. }\end{array}$ & 65 & 59 & 34 & 11 & 6 & 175 \\
\hline 11. & $\begin{array}{l}\text { Human Resource Accounting should give proper importance there } \\
\text { should be a specific and common accepted accounting system. }\end{array}$ & 52 & 64 & 37 & 18 & 4 & 175 \\
\hline 12. & There should be specific Accounting Standard for HRA. & 60 & 51 & 39 & 16 & 9 & 175 \\
\hline 13. & $\begin{array}{l}\text { Human Resource Accounting helps for the development of the } \\
\text { employees and for the firm as well. }\end{array}$ & 75 & 60 & 29 & 7 & 4 & 175 \\
\hline \multirow[t]{3}{*}{14.} & $\begin{array}{l}\text { Human Resource Accounting increases the value of the firm and its } \\
\text { prestige. }\end{array}$ & 76 & 48 & 32 & 13 & 6 & 175 \\
\hline & Total & 926 & 758 & 505 & 178 & 83 & 2,450 \\
\hline & Score in \% & 37.80 & 30.94 & 20.61 & 7.27 & 3.39 & 100 \\
\hline
\end{tabular}

The above beliefs of Students for disclosure of Human Resource Accounting information in annual reports of the company may also be presented in graphical manner as follows:

Graph 1: Students' Perception For Disclosure Of Human Resource Accounting:

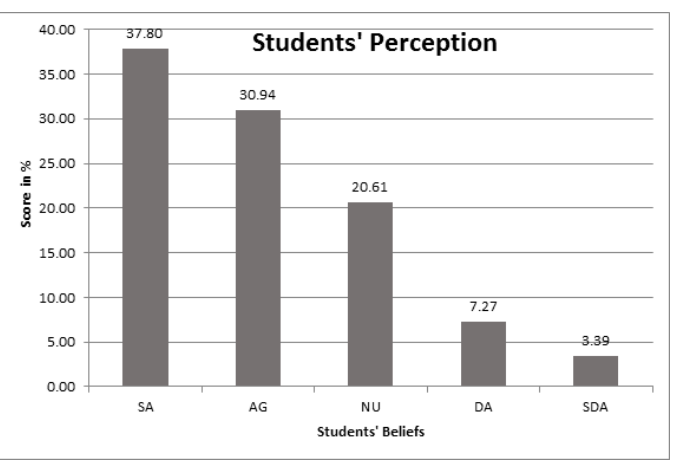

\section{CONCLUSION:}

The above analytical Table 1 presents in Part-I, disclose the beliefs of Students for presentation of specific Human Resource information. In the case of first information (i.e. number of students), out of 175 respondents, 102 respondents are in view to incorporate and present the information of number of employees in annual report. It means $58.29 \%$ respondents are in belief for presentation of such information.

By this way, all 17 information have been observed and analysed that on an average 95.88 responses out of 175 are in favour of presentation of Human Resource Accounting information i.e. $54.79 \%$ responses. It shows that majority people are in favour of Human Resource Accounting reports and its presentation.

Further in Part-II, after questioning different expectation in regard to Human Resource Accounting information, it has been analysed that, out of total 2,450 responses, 926 responses are strongly agree for presenting information. i.e. $37.80 \%$ responses are in favour; 758 responses are agree for presenting information, i.e. $30.94 \%$ responses are in favour of presentation of Human Resource Accounting in annual report.

Therefore, it can be said that 1,684 responses are in favour i.e. $68.73 \%$ responses are in positive approach for of presentation of information for Human Resource Accounting Disclosure.

\section{Abbreviation:}

$\mathrm{SA}=$ Strongly Agree

AG $=$ Agree

$\mathrm{NU}=$ Neutral

$\mathrm{DA}=$ Disagree

$\mathrm{SDA}=$ Strongly Disagree

\section{REFERENCES:}

(1) Agarwal N. P., Tailor R. K (2009), "Human Resource Management"- RBSA Publishers

(2) Edvinsson Lief, (2003), Knowledge Summit January 2003, Sharing Best Practices for Implementing Successful Knowledge Management Initiatives, The Hague, Netherlands. 